\title{
The Effects of Product Quality on Customer Satisfaction and Loyalty: Evidence from Malaysian Engineering Industry
}

\author{
Ling Chen Hoe, DBA \\ Senior GM (Meiden Malaysia Sdn Bhd) \\ Senior Lecturer, Sunway College, KL, Malaysia \\ Shaheen Mansori, $\mathrm{PhD}$ \\ Malaysia University of Science and Technology, Malaysia
}

Received: September 20, 2018 Accepted: November 19, 2018 Published: November 23, 2018

doi:10.5296/ijim.v3i1.13959

URL: https://doi.org/10.5296/ijim.v3i1.13959

\begin{abstract}
Organizations today are operating in an environment in which little is certain, the tempo is quicker and the dynamics are more complex. The customer is central to the organization and assessing customer satisfaction is a vital element in any strategy for business performance improvement. This makes customer satisfaction a driver for survival, competitiveness and growth. The key determinant for a sustainable business is customer loyalty as loyal customers not only increase the value of the business, but they also enable businesses to maintain costs lower than those associated with attracting new customers. By creating and preserving customer loyalty, organizations develop a long term, mutually beneficial relationship with the customers. The purpose of the research is to study the factors that can assist a company to build a sustainable competitive advantage through the effective enhancement of customer satisfaction and ultimately customer loyalty. The proposed conceptual model consists of the different dimensions of product quality as the independent variables with customer satisfaction. Garvin's eight dimensions of Product Quality in Performance, Features, Reliability, Conformance, Durability, Serviceability, Aesthetics and Perceived quality are dimensions of Product Quality that affect Customer Satisfaction which impacts Loyalty. The results provide insights to understand the dimensions of Product Quality that affect customer satisfaction and higher satisfaction leads to higher customer loyalty in the engineering industry in Malaysia.
\end{abstract}

Keywords: Product quality, Customer satisfaction, Customer loyalty 


\section{Introduction}

Competitive advantage is vital for an organization's survival and development in the market. Unless the organization develops and adapts its competitive strategy to the prevailing and changing conditions in the market, let alone to achieve its objectives, its continuous survival in the market is doubtful. Understanding the anatomy of competitive advantage is therefore of paramount importance to organizations for a long term survival and success. Organizations can gain competitive advantage when they are able to create and implement an innovative strategy that is not implemented by their competitors (Ma, 1999). Galbearth (2009) highlights positioning approach (Porter, 2008) and the resource-based view (RBV) (Wernerfelt, 1984) as the two dominant perspectives of competitive advantage for a firm.

Tangible assets alone no longer can provide sustainable competitive advantages (Rodriguez Perez \& Ordóñez de Pablos, 2003). The resource-based theory hinges on the premise that the source of competitive advantage lies in an organization's internal resources as opposed to their positioning in the external environment (Barney, 2001). This theory predicts that specific types of resources owned and controlled by firms have the impetus to generate competitive advantage and superior firm. A key to the success of an organization to create a sustained competitive advantage is their ability to identify and build their distinctive competencies, in order to produce the greatest value for all stakeholders (Bryson, Ackermann, \& Eden, 2007).

Sustained competitive advantage (SCA) is achieved when other competitors are not able to duplicate the organization's developed strategy (Rijamampianina, Abratt, \& February, 2003). SCA is the key differentiator of the organization in making its competition irrelevant. Competitive advantage is not static; rather, it is extremely dynamic in nature, since it has to be as flexible as market conditions, especially when customer needs and resources availability are highly variables time to time.

Change in technology has changed the competition landscape. Traditional way of controlling the resources simply does not work as small players also can have access to the advance level of technology with a very affordable cost by using the available open source information or the leasing facilities. Since sources of competitive advantage become scarcer, potential new areas of competitive advantage must be explored (Markley \& Davis, 2007). Competitive advantage is created as a firm discovers a new or a more efficient way as compared to its competitors or as soon as it innovates. Defining the source of innovation is equivalent to describing the ways to create competitive advantages, possible through five main sources of innovation: 1) the new technologies; 2) the modification of the demand or a new demand; 3 ) the occurrence of a new segment; 4) the changes in the costs or the availability of means of production; 5) the changes in the regulation (Passemard \& Kleiner, 2000).

Clulow et al. (2003) see organizations as sustaining competitive advantage only if they are able to continuously provide value to their customers. When this happens, customers are identified and their needs are communicated throughout the entire organization, and every employee evaluates every process, every task, and every decision by asking one vital question: "How will this add value for our customers?" (Whiteley \& Hessan, 1996). 


\section{Macrothink}

Overall an organization should be able to create superior customer value (Day, 1990). Adopting a customer centric vision enables an organisation understand their customers 1000 years ago, to win without a fight should be the supreme among all strategies. A firm can, under certain situations, win without fight by carefully positioning itself through innovation which affords it competitive advantages.

Building a competitive advantage involves understanding the needs of the market (customers) and devising a strategy to make use of the resources that are available (or can be obtained) to set the business apart from the competition. The strategy needs to take into account the target market and the company's strengths and weaknesses. Despite the high number of researches that explain and study the significant impact of creating sustainable competitive advantages of the performance of the company, still there are not many literature that focus on the factors of competitive advantage from service and product perspective (for example; service quality, product quality) in business to business (B2B) sector.

Thus, the primary aim of this research is to study the factors that can influence the customer satisfaction and consequently customer loyalty. The preceding sections of the literature review have focused on how organizations can achieve competitive advantage. From the literature review, it has been ascertained that both the internal factors (organization's human resource capability) and external factors (business environment) are important in determining the critical success factors for organizational performance. The focus of this research is on the internal factors of the organization, namely the product quality of organizations and its effects on customer satisfaction and loyalty.

\section{Literature Review}

The following section develops the conceptual framework for the research in seeking to understand better customer's needs and expectations to be derived from the following literature review.

\subsection{Product Quality}

(Deming, 1982) taught that by adopting appropriate principles of management, organizations can increase quality and simultaneously reduce costs. The objective of TQM as described by (Deming, 1982) is to develop and sustain a competitive advantage through achieving utmost efficiency manifested in cost reduction and improvement of customer satisfaction. Besides Deming, many have contributed to the growth of quality management with some of them having become known as quality gurus as follows (Waters \& Waters, 2008):

Fiegenbaum (1986) looked at failure costs and developed the idea of total quality involving everyone in an organization. Taguchi (1982) showed the importance of product design and process control that results in quality products. Juran (1979) emphasized the role of top management and customer focus. Crosby (1979) analyzed the total costs of quality and methods for implementing quality management. Ishikawa (1963) emphasized the contribution of workers to quality and introduced the concept of quality circles.

Total quality management (TQM) is an approach to improving the competitiveness, 
effectiveness and flexibility of a whole organization. It is essentially a way of planning, organizing and understanding each activity. TQM involves placing the customer as the focal point of operations. The aim is to continuously improve process performance in order to satisfy customer requirements (Zairi \& Sinclair, 1995). (Kelsey \& Bond, 2001) see TQM as an integrated management system focused on customer satisfaction and continuous improvement involving all employees in an organization.

(Guest, 2011) has argued that TQM is inextricably linked to HRM as a commitment to quality management is one component of the business strategy. Without top management involvement, commitment and leadership, a quality management program cannot succeed. (Karia \& Hasmi, 2006) in their study of quality management practices in Malaysia found that they were positively correlated with employees' work-related attitudes such as job involvement, job satisfaction, career satisfaction and organizational commitment. (Mehra \& Ranganathan, 2008) found that quality management substantially increases customer satisfaction across diverse industrial and cultural settings.

There are many different definitions and dimensions of product quality to be found in academic literature. Quality has been defined in four categories namely excellence, value for money, conformity to requirements and meeting of customer's requirements (Reeves \& Bednar, 1994). 8 critical factors for product quality have been developed and utilized by the researchers concerned - (Saraph et al., 1989, Flynn et al., 1994), (Black \& Porter, 1996), (Zeitz et al., 1997) and (Rao et al., 1999). They are Top Management support, Quality information availability, Quality information usage, Employee training, Employee involvement, Product/process design, Supplier quality and customer orientation.

Quality is a complex and multifaceted concept. In its broadest sense, product quality is the ability of a product to meet or exceed customer's expectations (Waters \& Waters, 2008). The most common operational definition posits quality as the customer's perception of product and service excellence. In today's competitive environment, quality is the key to an organization's success and survival. Intense global competition has highlighted the increasing importance of quality. Superior quality no longer differentiates competitors; instead, it validates the worthiness of a company to compete (Giffi et al., 1990).

(Garvin, 1987) developed a system of thinking about the quality of products by describing the basic elements of product quality in eight dimensions. (Garvin, 1987): (Foster, 2001): pointed out that quality is multidimensional and that each of its dimensions can be used strategically to gain competitive advantage.

The following is a summary of Garvin's eight dimensions of Product Quality:

1) Performance refers to a product's primary operating characteristics.

2) Features are additional characteristics that enhance the appeal of the product to the customer. These are the secondary aspects of performance.

3) Reliability is the likelihood that a product will not fail within a specific time period when put in use. 


\section{Macrothink}

4) Conformance is the precision with which the product or service meets the specified standards.

5) Durability measures the length of a product's operating life.

6) Serviceability is the speed, ease and costs with which the product can be put back into service when it breaks down.

7) Aesthetics refers to how the product looks, feels, sounds etc. It is a matter of personal judgement and a reflection of individual preference.

8) Perceived quality is the quality attributed by the customer, noting that perception is not always reality.

\section{Garvin's 8 Dimensions of [Product] Quality}

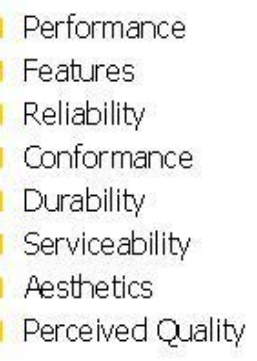

Garvin, D. "Competing on the Eight Dimensions of Quality." Harvard Business Review 65:6 (1987): 101-109.

Figure 1. The 8 dimensions of product quality (Garvin, 1987)

According to (Garvin, 1987), recognition of these eight dimensions is important for strategic purposes. An organization that chooses to compete on the basis of quality can do so in several ways; it need not pursue all eight dimensions at once. Instead, a segmentation strategy can be followed, with a few dimensions singled out for special attention.

\subsection{Customer Satisfaction}

Customers today have different needs and increasingly demand for higher quality of products and services. However, in majority of case customer priorities often differ significantly from what organizations think they are (Quinn \& Humble, 1993). While the needs of customers has been recognised as being of crucial importance but that understanding has not yet been fully translated into action in terms of accessing the necessary information.

In general definition "quality" is "satisfying customer's requirements" (Ghobadian, Speller, \& Jones, 1994). What quality means for the customer today no longer constitutes a competitive weapon but the basic core offering expected by customers Drucker (2005) suggests that the sole purpose of any organization is to create value for its customers. To enjoy superior performance, we need to serve the customer in distinctive ways to attract, 
satisfy and retain them (Hax \& Wilde, 2003).

Customer satisfaction goes beyond service experience that a customer went through. It incorporates value judgment and comparison to initial expectation of what the service quality should be; oftentimes based it is an overall comparison between the value that customers perceive and the price that they pays (Rust \& Zahorik, 1993). By focusing on customer value organizations think outwards, toward external customers and about ways in which customers can achieve greater responsiveness to their needs (Wooduff, 1997). Fulfillment of customer needs through delivering customer value, in turn increases customer loyalty (Gronholdt, Martensen, \& Kristensen, 2000).

\subsection{Customer Loyalty}

Lovelock (1983) conceptualized loyalty as the willingness of a customer to maintain a relationship with the firm, continue to purchase and use its products or services and likely to recommend the firm to others. Similarly, Gremler and Brown (1996) defined customer loyalty as those who repeat purchase from the same product and service provider.

Cronin and Taylor (1992) stated that the relationship between service quality and customer satisfaction has a direct impact on customer's loyalty as the universal understanding that keeping a loyal base of customers is much profitable for a company than attracting new customers. The results of Brown and Chen's (2001) study supported the contentions that there is a positive correlation between loyal customers and profitability. Loyal customers are likely to provide repeat business and were less likely to shop around than non-loyal customers (Oliver, 2010).

Building customer loyalty is a business strategy to boost loyalty and maximize share of customers. The pursuit of customer loyalty is a perpetual one. It is more of a journey than a destination. Customer loyalty yields significant benefits if its pursuit is part of an overall business strategy (Sower, Duffy, Kilbourne, Kohers, \& Jones, 2001). According to Jones (1996), customer loyalty is a prime determinant of long-term performance of organizations. Increasing customer satisfaction and customer retention leads to improved profits, positive word-of-mouth and lower marketing expenditures (Heskett \& Sasser Jr, 2010).

The research of McMullan and Gilmore (2008) emphasizes the importance of a differentiated approach to developing and managing customer loyalty by providing them value in the products and services offering. By focusing on customer value organizations think outwards, toward external customers and about ways in which customers can achieve greater responsiveness to their needs (Wooduff, 1997). Organizations focus on achieving customer satisfaction and loyalty by delivering superior value, an underlying source of competitive advantage (Yang \& Peterson, 2004).

Customer loyalty is one of the most important customer metrics in marketing due to the profit impact of maintaining a loyal customer base (Oliver, 2010). The literature points out that customer loyalty lead to firm profitability because customer loyalty positively influences firm product-marketplace performance (Anderson \& Mittal, 2000) and financial performance (Gupta \& Zeithaml, 2006). Brown and Chen (2001) propose three approaches used to 


\section{Macrothink}

measure customer loyalty: 1) Behavioural measurement; 2) Attitudinal measurement; 3) Composite measurement.

Behavioural measurements consider continuous, repetitious purchase behaviour as an indicator of loyalty. The attitudinal measurements use attitudinal information to show the emotional and psychological attachment inherent in loyalty, which include intentions for re-purchase and the spreading of positive word-of-mouth about a product or service. Composite measurement of loyalty combines both behavioural and attitudinal dimensions (Rundle-Thiele \& Maio, 2001). It measures loyalty in terms of preferences as a result of trust in a product or service further explaining that a customer is sincerely loyal only when brand commitment is present, which in turn is "mediated by a high degree of affective and cognitive brand conviction and attitude strength." When a customer is said to have strong resistance to change brands and have durable conviction over time, there is a high tendency to be committed to a brand, resulting to measurement of loyalty.

\section{Conceptual framework}

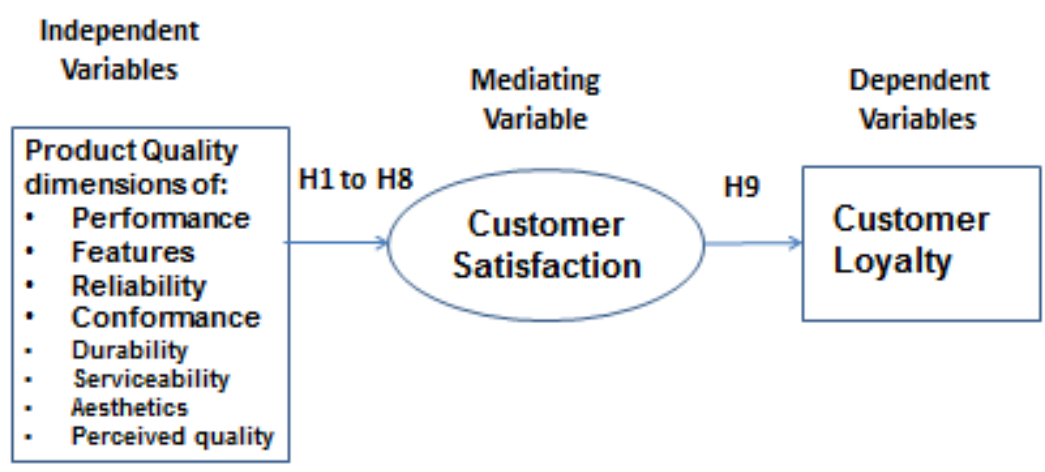

Figure 2. Conceptual framework

Customer-perceived quality represents a key determinant of sustainable business success (Bartikowski et al., 2010). (Kumar et al., 2009) provides evidence of the positive impact of quality on company performance regarding the four domains of company performance studied, in particular employee relations (participation and morale), operating procedures (improved products and services quality and productivity), customer satisfaction (reduced number of customer complaints) and performance (increased profitability). Based on the literature reviewed, it is recommended that Garvin's framework of the 8 dimensions of product quality be used in the research survey questionnaires to study and evaluate the implementation of product quality management in the organization.

Hence, the following hypotheses were developed to test this phenomenon.

\section{Hypotheses}

H1 There is a direct relationship between Performance and Customer Satisfaction; 
H2 There is a direct relationship between Features and Customer Satisfaction;

H3 There is a direct relationship between Reliability and Customer Satisfaction;

H4 There is a direct relationship between Conformance and Customer Satisfaction;

H5 There is a direct relationship between Durability and Customer Satisfaction;

H6 There is a direct relationship between Serviceability and Customer Satisfaction;

H7 There is a direct relationship between Aesthetics and Customer Satisfaction;

H8 There is a direct relationship between Perceived quality and Customer Satisfaction;

H9 There is a positive relationship between Customer Satisfaction and Loyalty.

\section{Methodology}

The selection of an appropriate methodology is fundamental to the success of any research project. In choosing a methodology for conducting their research, researchers must balance theoretical ambition with the practical constraints. There is no one best way of conducting research, rather the method needs to be chosen to suit the specific circumstances of the research (Babbie, 2015). A descriptive research method's main purpose is to describe the characteristics and details of the population such as who, what, when, where and how (Yin, 2013). Therefore, to carry out the study to ascertain customer satisfaction and its relationships with the variables identified in the conceptual framework, quantitative primary data collection is proposed to be collected using survey questionnaires via email to be sent to customers of the different business segments of the industry.

Section A of the survey questionnaire consists of questions on organizational profile while Section B solicits responses from the respondents representing their respective organizations on the variables from the model developed for the research. Participants were asked to consider aspects of the major suppliers of the company that provide parts, service, and/or raw materials that have high contribution in their business processes and productions. Likert-type scales are by far the most common survey instrument for attitude measurement based on three reasons, namely: conformity with current research practice, ease of scale construction and standards for measurement evaluation that align with test theory (Bartikowski, Kamei, \& Chandon, 2010). A commonly used 5-point Likert scale format is used to measure satisfaction (McMullan, 2005). For Section B, a 5 point Likert scale measurements were administered, ranging from 1 (representing strongly disagree) to 5 (representing strongly agree) with 3 indicating neutral.

\section{Data Analysis and Discussion}

For the purpose of this research a link to the survey questionnaires in Google Docs was sent by email to 90 authorized personnel from the Procurement Department to respond on behalf of their respective organization. Strategic Business Units (SBU) within an organization is considered independently due to the differences in their business focus. 78 responses were successfully collected from participants and included into the final analysis. 


\section{Macrothink}

The research sets out to find the dimensions of service quality that affect customer satisfaction and the mediating effects of customer satisfaction on customer loyalty in the electrical engineering industry in Malaysia. The following is the breakdown of the Private / Public sector profile of the customer organizations. The majority of the customer organizations (87.2\%) represent the Private sector while the remaining $12.8 \%$ are from the

Public sector.

Table 1. Organizational profile

\begin{tabular}{lccc}
\hline & Frequency & Percent & Cumulative Percent \\
\hline Sector & & & \\
\hline Private & 68 & 87.2 & 87.2 \\
Public & 10 & 12.8 & 100.0 \\
Total & 78 & 100.0 & \\
\hline Industry & & & 9.0 \\
Construction & 7 & 9.0 & 50.0 \\
Manufacturing & 32 & 41.0 & 80.8 \\
Power & 24 & 30.8 & 93.6 \\
Railway & 10 & 12.8 & 100.0 \\
Water & 5 & 6.4 & \\
Total & 78 & 100.0 & \\
Size of organization turnover & & & 56.4 \\
More than RM 50 Million & 44 & 56.4 & 75.6 \\
RM 10 - 50 Million & 15 & 19.2 & 100.0 \\
Up to RM 10 Million & 19 & 24.4 & \\
Total & 78 & 100.0 & \\
\hline
\end{tabular}

The following is the breakdown of the Industry the customer organizations are in. The majority are from the Manufacturing (41\%) and Power (30.8\%) industry while Railway, Construction and Water make up the remaining industries.

The size of the customer organizations in terms of turnover is shown below. Majority $(56.4 \%)$ has a turnover of more than RM 50 Million with the balance almost evenly split between those with RM 10-50 Million (19.2\%) and those with Up to RM 10 Million turnover (24.4\%).

The country of origin of the customer organizations are represented below. Most of the customer organizations are local (Malaysian) at $67.9 \%$ with a sizeable of Japanese origin (24.4\%). French and Korean although small in percentage make up the remaining. 


\subsection{Validity and Reliability Test}

Table 2. Reliability and validity

\begin{tabular}{|c|c|c|c|c|}
\hline & $\begin{array}{l}\text { Factor } \\
\text { Loading }\end{array}$ & AVE & $\mathrm{CR}$ & $\begin{array}{c}\text { Cronbachs } \\
\text { Alpha }\end{array}$ \\
\hline \multicolumn{5}{|l|}{ Performance } \\
\hline $\begin{array}{l}\text { Current supplier's product performance is important to } \\
\text { my organization }\end{array}$ & 0.790 & 0.721 & 0.885 & 0.807 \\
\hline Product performance always meets our requirements & 0.911 & & & \\
\hline $\begin{array}{l}\text { Current supplier's products performance meet } \\
\text { requirements better than others options in market }\end{array}$ & 0.842 & & & \\
\hline \multicolumn{5}{|l|}{ Features } \\
\hline $\begin{array}{l}\text { Current supplier product features is what we need for } \\
\text { our operation }\end{array}$ & 0.797 & 0.661 & 0.854 & 0.742 \\
\hline $\begin{array}{l}\text { Current supplier's product features are desirable \& } \\
\text { useful }\end{array}$ & 0.848 & & & \\
\hline $\begin{array}{l}\text { Current supplier's product features are more desirable } \\
\& \text { useful than other competitors }\end{array}$ & 0.793 & & & \\
\hline \multicolumn{5}{|l|}{ Reliability } \\
\hline $\begin{array}{l}\text { Current supplier's product reliability can meet my } \\
\text { organization needs }\end{array}$ & 0.654 & 0.645 & 0.843 & 0.715 \\
\hline Current supplier's product is always reliable & 0.863 & & & \\
\hline $\begin{array}{l}\text { Current supplier's product is more reliable than other } \\
\text { competitors }\end{array}$ & 0.872 & & & \\
\hline \multicolumn{5}{|l|}{ Conformance } \\
\hline $\begin{array}{l}\text { Current supplier's product conformance can meet my } \\
\text { organization needs }\end{array}$ & 0.803 & 0.711 & 0.881 & 0.796 \\
\hline $\begin{array}{l}\text { Current supplier's product always conforms to } \\
\text { requirements }\end{array}$ & 0.904 & & & \\
\hline $\begin{array}{l}\text { Current supplier's product is more conformant than } \\
\text { other competitors }\end{array}$ & 0.820 & & & \\
\hline \multicolumn{5}{|l|}{ Durability } \\
\hline $\begin{array}{l}\text { Current supplier's product durability is important to my } \\
\text { organization }\end{array}$ & 0.683 & 0.682 & 0.864 & 0.765 \\
\hline Current supplier's product is always durable & 0.910 & & & \\
\hline $\begin{array}{l}\text { Current supplier's product is more durable than other } \\
\text { competitors }\end{array}$ & 0.868 & & & \\
\hline \multicolumn{5}{|l|}{ Aesthetics } \\
\hline $\begin{array}{l}\text { Current supplier's product aesthetics is important to my } \\
\text { organization }\end{array}$ & 0.863 & 0.773 & 0.911 & 0.853 \\
\hline Current supplier's product is aesthetic & 0.923 & & & \\
\hline $\begin{array}{l}\text { Current supplier's product is more aesthetic than other } \\
\text { competitors }\end{array}$ & 0.850 & & & \\
\hline
\end{tabular}




\begin{tabular}{|c|c|c|c|c|}
\hline \multicolumn{5}{|l|}{ Serviceability } \\
\hline $\begin{array}{l}\text { Current supplier's product serviceability is important to } \\
\text { my organization }\end{array}$ & 0.749 & 0.701 & 0.875 & 0.785 \\
\hline $\begin{array}{l}\text { Current supplier's product has high level of } \\
\text { serviceability }\end{array}$ & 0.905 & & & \\
\hline $\begin{array}{l}\text { Current supplier's product is more serviceable than } \\
\text { other competitors }\end{array}$ & 0.850 & & & \\
\hline \multicolumn{5}{|l|}{ Perceived Quality } \\
\hline $\begin{array}{l}\text { Current supplier's product quality can meet our } \\
\text { standards }\end{array}$ & 0.680 & 0.664 & 0.854 & 0.748 \\
\hline Current supplier's product has high quality & 0.911 & & & \\
\hline $\begin{array}{l}\text { Current supplier product is of better quality than other } \\
\text { suppliers }\end{array}$ & 0.836 & & & \\
\hline \multicolumn{5}{|l|}{ Satisfaction } \\
\hline Current supplier has a strong focus on its customers & 0.847 & 0.716 & 0.946 & 0.932 \\
\hline $\begin{array}{l}\text { Current supplier's product design differentiates it from } \\
\text { that of others }\end{array}$ & 0.663 & & & \\
\hline $\begin{array}{l}\text { Current supplier's employees are motivated to serve its } \\
\text { customers }\end{array}$ & 0.836 & & & \\
\hline $\begin{array}{l}\text { Current supplier's top management are committed to } \\
\text { customer satisfaction }\end{array}$ & 0.876 & & & \\
\hline $\begin{array}{l}\text { Current supplier engages in continual monitoring of its } \\
\text { customer satisfaction activities }\end{array}$ & 0.871 & & & \\
\hline $\begin{array}{l}\text { Current supplier engages in a continuous improvement } \\
\text { cycle }\end{array}$ & 0.914 & & & \\
\hline $\begin{array}{l}\text { Current supplier engages in activities to add value to its } \\
\text { customers }\end{array}$ & 0.894 & & & \\
\hline \multicolumn{5}{|l|}{ Loyalty } \\
\hline $\begin{array}{l}\text { My organization finds that current supplier can be } \\
\text { counted on to do what is right }\end{array}$ & 0.924 & 0.662 & 0.946 & 0.936 \\
\hline $\begin{array}{l}\text { My organization finds that current supplier has high } \\
\text { integrity }\end{array}$ & 0.968 & & & \\
\hline $\begin{array}{l}\text { My organization finds that current supplier is } \\
\text { trustworthy }\end{array}$ & 0.949 & & & \\
\hline $\begin{array}{l}\text { My organization tell others about our experiences with } \\
\text { current supplier }\end{array}$ & 0.880 & & & \\
\hline $\begin{array}{l}\text { My organization recommends current supplier's } \\
\text { products and services to others }\end{array}$ & 0.958 & & & \\
\hline $\begin{array}{l}\text { My organization encourage others to use current } \\
\text { supplier's products and services }\end{array}$ & 0.939 & & & \\
\hline $\begin{array}{l}\text { My organization intend to continue the business with } \\
\text { the current supplier }\end{array}$ & 0.881 & & & \\
\hline $\begin{array}{l}\text { Current supplier is my organization's first consideration } \\
\text { as product and service provider }\end{array}$ & 0.931 & & & \\
\hline My organization will continue to be a loyal customer & 0.925 & & & \\
\hline
\end{tabular}


The results from table 2 indicate that all variables have acceptable level of validity level as all AVEs (more than 0.5) and CRs (more than 0.7) could meet the minimum required threshold. In addition, the developed construct variables show high level of reliability as the calculated Cronbach's Alpha for all variables are above 0.7 minimum threshold.

Table 3. Hypotheses Testing

\begin{tabular}{lccccc}
\hline & Sample & Standard & & & \\
& Mean & Error & T-Value & P-Value & Supported \\
\hline H1: Performance $\rightarrow$ Satisfaction & 0.036 & 0.120 & 0.279 & 0.7807 & No \\
H2: Features $\rightarrow$ Satisfaction & 0.165 & 0.088 & 1.865 & 0.0651 & No \\
H3: Reliability $\rightarrow$ Satisfaction & 0.063 & 0.110 & 0.578 & 0.5646 & No \\
H4: Conformance $\rightarrow$ Satisfaction & -0.045 & 0.109 & 0.394 & 0.6941 & No \\
H5: Durability $\rightarrow$ Satisfaction & 0.260 & 0.109 & 2.334 & 0.0216 & Yes \\
H6: Serviceability $\rightarrow$ Satisfaction & 0.375 & 0.085 & 4.300 & 0.0001 & Yes \\
H7: Aesthetics $\rightarrow$ Satisfaction & 0.148 & 0.060 & 2.502 & 0.0140 & Yes \\
H8: Perceived Quality $\rightarrow$ Satisfaction & 0.357 & 0.116 & 3.101 & 0.0025 & Yes \\
H9: Satisfaction $\rightarrow$ Loyalty & 0.779 & 0.034 & 22.817 & 0.0001 & Yes \\
\hline Satisfaction R2 $=$ & 0.573 & & & & \\
Loyalty R2 $=$ & 0.604 & & & & \\
\hline
\end{tabular}

The output results from the bootstrap of 5000 samples show that hypotheses 1,2,3 and 4 are not supported as the calculated p-values are more than $0.05\left(\mathrm{H}_{1}\right.$ : p-value Performance $\rightarrow$ Satisfaction $=0.7807, \mathrm{H}_{2}$ : p-value Features $\rightarrow$ Satisfaction $=0.0651, \mathrm{H}_{3}$ : p-value Reliability $\rightarrow$ Satisfaction $=0.5646, \mathrm{H}_{4}: \mathrm{p}$-value Conformance $\rightarrow$ Satisfaction=0.6941).

In addition, the results indicate that hypotheses 5,6,7,8 and 9 are supported as the calculated p-value related to these hypotheses is less than $0.05\left(\mathrm{H}_{5}\right.$ : p-value Durability $\rightarrow$ Satisfaction: $0.0216 / \beta=0.261, \mathrm{H}_{6}: \mathrm{p}$-value Service $\rightarrow$ Satisfaction: $0.000 / \beta=0.375, \mathrm{H}_{7}: \mathrm{p}$-value Aesthetics $\rightarrow$ Satisfaction: $0.0141 / \beta=0.148, \quad$ H8: $p$-value Perceived Quality $\rightarrow$ Satisfaction $=0.0025 / \beta=0.357$, H9: $p$-value Satisfaction $\rightarrow$ Loyalty $=0.0001 / \beta=0.779$ ).

Overall it can be observed that Serviceability and Perceived Service Quality have highest impact on Customer Satisfaction followed by Durability and Aesthetics aspect of industry products. Finally, the current results show that Satisfaction has high and influence on the level of Loyalty for industry products (H9: $p$-value Satisfaction $\rightarrow$ Loyalty $=0.001 / \beta=0.78$ ).

\subsection{Managerial Discussion}

This study seeks to understand the relationships between the variables identified from literature review that form the conceptual framework affecting companies in the electrical engineering industry in Malaysia to contribute to the expansion of the scholarship.

For Product Quality, the areas highlighted by the Procurement representatives of customer 
organizations as significant are Durability, Serviceability, Aesthetics and Perceived Quality. Results indicate that Serviceability and Perceived Quality has the highest impact on Customer Satisfaction, leading to Loyalty.

The results also indicate that Performance, Features, Reliability have influence on satisfaction but this relationship is not significant. A possible explanation for this could be due to the difference in emphasis of the Procurement personnel whom may stress on cost as their main priority. This is in line with the findings of Saleki and Sayedsaleki (2012): that price influences purchasing behavior and Jaafar et al. (2012): that perceived value affect purchasing. Mwikali and Kavale (2012)'s study of suppliers' selection in the African context confirms the same.

To improve on Customer Satisfaction, the following has been highlighted by the customers as the area of importance, namely a product design that differentiates from that of others in terms of Serviceability, Perceived Quality, Durability and Aesthetics. Companies should seek to build products based on the concepts of value innovation in order to create value for the customers by improving on the aspects of the product quality that have been identified by the customers' representatives. This may require research and development for the products that a superior to that of competitors offering that meet the needs of the customers and on the future needs of the market. The improvements in Product Quality may also require investments in the organization's human resources to address the above concerns highlighted by the customer's representatives. It is therefore recommended for companies to review its talent management program from the stages of attraction, training, development and retention of their employees. Ways to engage and motivate their employees must also be reviewed taking into consideration best practices in the industry.

\section{Limitations and Recommendations for Further Study}

A cross sectional study was undertaken to ascertain the customer's feedback. It may be difficult to expect a higher response rate as respondents may not fully see the benefit of the research, thus curtailing their efforts or even limiting their participation. Recommendations for future research can be made to address the limitations of this research, namely to carry out a longitudinal study can be conducted as the expectation and requirements of customers can change over time. As the sample size of 78 is relatively small, further research could be done to replicate this study with other customer organizations in the industry to further validate its findings. A qualitative approach using one on one interview or focus groups can be considered for triangulation of findings to explore more insights and justify the current results that indicate Performance, Features, Reliability and Conformance are not significant contributor to the satisfaction of customers for industrial products.

\section{References}

Anderson, E. W., \& Mittal, V. (2000). Strengthening the satisfaction-profit chain. Journal of Service Research, 3(2), 107-120. https://doi.org/10.1177/109467050032001

Babbie, E. (2015). The practice of social research. Cengage Learning. 


\section{Macrothink}

International Journal of Industrial Marketing ISSN 2162-3066 2018, Vol. 3, No. 1

Barney, J. B. (2001). Is the resource-based "view" a useful perspective for strategic management research? Yes. Academy of Management Review, 26(1), 41-56.

Bartikowski, B., Kamei, K., \& Chandon, J. L. (2010). A verbal rating scale to measure Japanese consumers' perceptions of product quality. Asia Pacific Journal of Marketing and Logistics, 22(2), 179-195. https://doi.org/10.1108/13555851011026935

Bowen, J. T., \& Chen, S. L. (2001). The relationship between customer loyalty and customer satisfaction. International Journal of Contemporary Hospitality Management, 13(5), 213-217. https://doi.org/10.1108/09596110110395893

Bryson, J. M., Ackermann, F., \& Eden, C. (2007). Putting the Resource - Based View of Strategy and Distinctive Competencies to Work in Public Organizations. Public Administration Review, 67(4), 702-717. https://doi.org/10.1111/j.1540-6210.2007.00754.x

Clulow, V., Gerstman, J., \& Barry, C. (2003). The resource-based view and sustainable competitive advantage: The case of a financial services firm. Journal of European Industrial Training, 27(5), 220-232. https://doi.org/10.1108/03090590310469605

Day, G. S. (1990). Marketing Driven Strategy: Process For Creating Value. New York: Free Press.

Deming, W. E. (1982). Quality, productivity, and competitive position. Massachusetts Institute of Technology Center for Advanced En.

Drucker, P. F. (2005). Managing oneself. Harvard Business Review, 83(1), 100-109.

Field, A. (2009). Discovering Statistics using SPSS. Sage: London.

Galbreath, J. (2009). Building corporate social responsibility into strategy. European Business Review, 21(2), 109-127. https://doi.org/10.1108/09555340910940123

Garvin, D. A. (1987). Competing on the Eight Dimensions of Quality. Harvard Business Review, Nov.-Dec.

Gronholdt, L., Martensen, A., \& Kristensen, K. (2000). The relationship between customer satisfaction and loyalty: Cross-industry differences. Total Quality Management, 11(4-6), 509-514. https://doi.org/10.1080/09544120050007823

Gupta, S., \& Zeithaml, V. (2006). Customer metrics and their impact on financial performance. Marketing Science, 25(6), 718-739. https://doi.org/10.1287/mksc.1060.0221

Hax, A. C., \& Wilde, D. L. (2003). The Delta Model-a new Framework of strategy. Journal of Strategic Management Education, 1(1), 1-21.

Heskett, J. L., \& Sasser Jr, W. E. (2010). The service profit chain. Handbook of Service Science (pp. 19-29). Springer. https://doi.org/10.1287/mksc.1060.0221

Jaafar, S. N., Pan, E. L., \& Mohaini, N. (2012). Asian Journal of Business and Management Sciences, 2(8), 73-90. 
Jackson, S. E., \& Schuler, R. S. (1995). Understanding human resource management in the context of organizations and their environments. Strategic Human Resource Management, 46, 237-264. https://doi.org/10.1146/annurev.ps.46.020195.001321

Jones, T. O. (1996). Why satisfied customers defect. Journal of Management in Engineering, 12(6), 11-11. https://doi.org/10.1061/(ASCE)0742-597X(1996)12:6(11.2)

Khilji, S. E., Davis, E. B., \& Cseh, M. (2010). Building competitive advantage in a global environment: Leadership and the mindset. The past, present and future of international business and management. Advances in International Management, 23, 353-373. https://doi.org/10.1108/S1571-5027(2010)00000230021

Lovelock, C. H. (1983). Classifying services to gain strategic marketing insights. The Journal of Marketing, 9-20. https://doi.org/10.1177/002224298304700303

Ma, H. (1999). Anatomy of competitive advantage: A Select framework. Management Decision, 37(9), 709-718. https://doi.org/10.1108/00251749910299129

Markley, M. J., \& Davis, L. (2007). Exploring future competitive advantage through sustainable supply chains. International Journal of Physical Distribution \& Logistics Management, 37(9), 763-774. https://doi.org/10.1108/09600030710840859

McMullan, R. (2005). A multiple-item scale for measuring customer loyalty development. Journal of Services Marketing, 19(7), 470-481. https://doi.org/10.1108/08876040510625972

McMullan, R., \& Gilmore, A. (2008). Customer loyalty: An empirical study. European Journal of Marketing, 42(9/10), 1084-1094. https://doi.org/10.1108/03090560810891154

Mwikali, R., \& Kavale, S. (2012). Factors Affecting the Selection of Optimal Suppliers in Procurement Management. International Journal of Humanities and Social Science, 2(14).

Newhall, S. (2012). A global approach to talent management: High-quality leaders are the key to competitive advantage. Human Resource Management International Digest, 20(6), 31-34. https://doi.org/10.1108/09670731211260870

Oliver, R. L. (2010). Satisfaction: A behavioral perspective on the consumer. ME sharpe.

Passemard, D., \& Kleiner, B. H. (2000). Competitive advantage in global industries. Management Research News, 23(7/8), 111-117. https://doi.org/10.1108/01409170010782307

Porter, M. E. (2008). The five competitive forces that shape strategy. Harvard Business Review, $86(1), 25-40$.

Rijamampianina, R., Abratt, R., \& February, Y. (2003). A framework for concentric diversification through sustainable competitive advantage. Management Decision, 41(4), 362-371. https://doi.org/10.1108/00251740310468031

Rodriguez, P. J., \& Ordóñez de Pablos, P. (2003). Knowledge management and organizational competitiveness: A framework for human capital analysis. Journal of Knowledge Management, 7(3), 82-91. https://doi.org/10.1108/13673270310485640 


\section{Macrothink}

International Journal of Industrial Marketing

ISSN 2162-3066 2018, Vol. 3, No. 1

Rundle-Thiele, S., \& Maio, M. M. (2001). Assessing the performance of brand loyalty measures. Journal of Services Marketing, 15(7), 529-546. https://doi.org/10.1108/EUM0000000006210

Rust, R. T., \& Zahorik, A. J. (1993). Customer satisfaction, customer retention, and market share. Journal of Retailing, 69(2), 193-215. https://doi.org/10.1016/0022-4359(93)90003-2

Saleki, Z. S., \& Sayedsaleki, S. M. (2012). The Main Factors Influencing Purchase Behaviour of Organic Products In Malaysia. Interdiscliplinary Journal of Contemporary Research in Business, 4(1).

Tyson, S. (1995). Human resource strategy: Towards a general theory of human resource management. Financial Times Management.

Waters, D., \& Waters, C. D. J. (2008). Quantitative methods for business. Pearson Education.

Wernerfelt, B. (1984). A resource - based view of the firm. Strategic Management Journal, 5(2), 171-180. https://doi.org/10.1002/smj.4250050207

Wooduff, R. (1997). Customer value: The next source for competitive advantage. J Acad Mark Sci, 25(2), 139-153. https://doi.org/10.1007/BF02894350

Yang, Z., \& Peterson, R. T. (2004). Customer perceived value, satisfaction, and loyalty: The role of switching costs. Psychology \& Marketing, 21(10), 799-822. https://doi.org/10.1002/mar.20030

Yin, R. K. (2013). Case study research: Design and methods. Sage publications.

Zeithaml, V. A., Parasuraman, A., \& Berry, L. L. (1990). Delivering quality service: Balancing customer perceptions and expectations. Simon and Schuster.

Zheng, W., Yang, B., \& McLean, G. N. (2010). Linking organizational culture, structure, strategy, and organizational effectiveness: Mediating role of knowledge management. Journal of Business Research, 63(7), 763-771. https://doi.org/10.1016/j.jbusres.2009.06.005

\section{Copyright Disclaimer}

Copyright for this article is retained by the author(s), with first publication rights granted to the journal.

This is an open-access article distributed under the terms and conditions of the Creative Commons Attribution license (http://creativecommons.org/licenses/by/3.0/). 